\title{
Peertechz
}
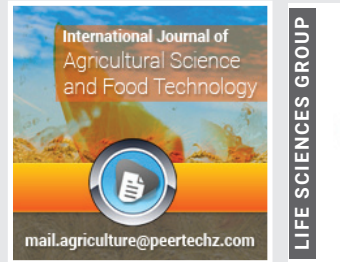

\section{Transitional Opportunities of the Family Farms to Agribusiness in Livestock Production in Cameroon}

Received: 22 April, 2019

Accepted: 12 December, 2020

Published: 14 December, 2020

*Corresponding author: Mbu Daniel Tambi, Department of Agricultural Economics; University of Dschang, West Region, PO Box 222 FASA, Cameroon, E-mail: tambi2015@yahoo.co.uk

Keywords: Opportunities; Transition; Family farms; Agribusiness; Livestock; Production; Cameroon

https://www.peertechz.com

\section{Check for updates}

\author{
Mbu Daniel Tambi* and Forchid Julius Anyah \\ Department of Agricultural Economics; University of Dschang, West Region, PO Box 222 \\ FASA, Cameroon
}

\begin{abstract}
This study seeks to catalogue the opportunities for livestock production in the North West Region of Cameroon. Using Google Earth Maps, twenty urban and twenty peri-urban points were randomly selected based on settlement, followed by a random selection of four livestock farmers per point to participate in this study. A random sample of 160 questionnaires was collected and analysed using the Statistical Package for the Social Sciences version 20.0. The result showed that farmers kept a variety of livestock species of which most were pigs followed by poultry. Although poultry were the second most common species kept, they were more important than all other species in the livelihoods of farmers due to their multiple roles. This study suggests that information on innovations in livestock production should be available to farmers to improve their production and sales.
\end{abstract}

\section{Introduction}

A strong and efficient agricultural sector has the potential to feed its growing population, generate employment, earn foreign exchange and provide raw materials for industries. Agriculture is a major source of livelihood throughout the world especially for the majority of people living in rural areas in developing countries. It has been noted that about $75 \%$ of the world population is rural and the main source of income of this population is agriculture. About 25000 people die every day in the world due to hunger or hunger related issues particularly in Africa [1]. Up to this century, poverty still remains prominent in the developing countries and one sixth of the world's population live below the poverty line of less than a dollar a day which is the extreme poverty level [2] and according to Lipton [3] $90 \%$ of them are small scale farmers (family farms).

Livestock have multiple roles in human society. They contribute substantially and directly to food security and to human health. For poor and under-nourished people, particularly children, the addition of modest amounts of livestock products to their diets can have substantial benefits for physical and mental health [1]. Livestock's contribution to livelihoods, particularly those of the poor in developing countries is also well recognized. Livestock generate income by providing both food and non-food products that the household can sell in formal or informal markets. Livestock acquisition as a pathway out of poverty has been documented by Sasson [2] in western Kenya. In addition to their food security, human health, economic and environmental roles, livestock have important social and cultural roles. In many parts of Africa, social relationships are partly defined in relation to livestock, and the size of a household's livestock holding may confer considerable social important. The sharing of livestock with others is often a means to create or strengthen social relationships, through their use as dowry or bride price, as allocations to other family members and as loans [4]. Social status in livestock-based communities is often associated with leadership and access to natural, physical and financial resources.

In Cameroon, the livestock sector represents about $9 \%$ of the total output and $2.1 \%$ of national GDP [5]. Animal production increased gradually between 1995 and 2006 making the sub sector a source of revenue to more than $30 \%$ of the rural 
population. The categories of livestock reared include cattle, sheep, goats, pig, and poultry. Cattle contributes about $54 \%$ of the total meat consumed per inhabitant, while the proportion of sheep is $13 \%$, goat is $14 \%$, poultry is $17 \%$ and $15 \%$ for pig [1]. Although the contribution of livestock sub-sector to the national Gross Domestic Product (GDP) is in the lowest level, it has been a crucial source of high quality protein, minerals and vitamins to the population of North west region in particular and Cameroon as a whole. These proteins are milk, meat and eggs. For many smallholder farmers, livestock is a 'living bank' that serves as a financial reserve for periods of economic distress [6].

Despite the importance of livestock to the population of the North West Region, the sector suffers from many challenges (i.e. diseases, high feeding cost, drought, price fluctuation, bird flu outbreak, theft, transhumance and its consequences, little or no livestock extension services) [4]. Bird Flu lastly hit the entire country in 2008 and caused actors in the sectors millions of FCFA as loss [5]. These challenges can lead to adversity or loss. For the livestock sector to play its rightful role in the agricultural sector in the North West region in particular and Cameroon as a whole, there is need to unlock the sector's potential. It is important to catalyze productivity, value addition, market access and trade through the identification of the different constraints and possible technologies, solutions and management practices that can enhance productivity and competitiveness [7].

Millions of the world's poor people rely on livestock for their livelihood, such as live animals, meat, milk, eggs, leather, fiber, manure. However, livestock production, management and accessing the market with livestock products is a risky business. Farmers face a variety of price, yield and resource risks that make their incomes unstable and unpredictable from year to year. Animals may be destroyed by drought or new pest outbreaks, input costs may increase and product prices may plummet because of adjustments in the local or world market [4]. The livelihoods of breeders depend to a large extent on livestock production, and their access to formal financial services is usually limited. Unless well-managed, livestock constraints and risks slow economic development and poverty reduction, and contribute to humanitarian crises [5].

Livestock production in communal areas in sub-Saharan Africa is constrained by a variety of factors. Feed shortages during the dry season constitute the greatest challenge in terms of quantity and quality [8]. According to Kassam [9], the main constraint is to increase livestock productivity and output is the lack of adequate supplies of good quality livestock feed in the dry season produced at a competitive cost and without jeopardizing household food security. Together with high incidences of diseases and mortality rates, feed shortages lead to low livestock productivity [8]. Unavailability of water is another common constraint. In some areas, water may be available but is of insufficient quality to support healthy growth and performance. Masikati [8] reported that water constraints were prevalent during the dry season, where animals had to walk distances of up to $14 \mathrm{~km}$ per day to access water. Water points are sometimes limited and large numbers of animals use the same points leading to high chances of spreading diseases and land degradation.

Muluh, et al. [4] pointed that the failure of government services could affect the veterinary health services. Other factors include poor housing, low soil fertility for forage production, and weak market chains for livestock and their products. These constraints are, however, within farmers' capacity to mitigate [8]. While the direct impacts of climate change on livestock disease over the next two to three decades may be relatively muted [10]. There are considerable gaps in knowledge on existing diseases of livestock and their relation to environmental factors. The aim of this study was therefore to catalogue the opportunities for increasing livestock production. Specifically: to describe the socio-economic characteristics of operators of family livestock farms in the North West region of Cameroon, to determine the animal species raised and the purpose for keeping the different species and to determine and analyze the technology mix and management practices for sustainability of family farms and fight against food insecurity in the region.

The various opportunities include regular monitoring, information useful for decision making on family farms and the keeping of Farm records. Beginning with regular monitoring, to move from livestock family farming to agribusiness, a number of challenges and opportunities imply. Animal health is a priority because the care and survival of one animal in family farm is just as important as many animals in agribusiness. To detect health problems in animals, it is necessary to observe them frequently, several times per day. When observing the animal, there is the need to check: (1) Behavior: does it react normally to its environment and in the group or is it acting strangely? (2) Attitude: does it carry its head, ears, body and tail as usual? Does it walk normally? (3) Condition: is the animal in good condition and is it well-muscled, neither too thin nor too fat? (4) Does it eat, drink and ruminate properly? (5) Does it urinate and defecate normally? [1].

Considering the information useful for decision making on family farms, the most useful asset a producer can have to help with the management of risk is good information. There are many sources of information available to the producer. The most appropriate place to look for information depends on the type of risk with which the farmer is concerned. Although the source of information of family farm operators is other family members and friends, they also turn to mass media particularly radio for information. Commercial farmers on the other hand tend to rely more on mass media (radio, television and newspapers more than on their friends, family members and neighbors (Agricultural Experiment Station, University of Missouri: Colin, 2005). Radio Networks and local neighborhood meetings for breeders can serve as vital sources of information for farmers who want to migrate from family farming to commercial farming or agribusiness [7].

Looking at the keeping of farm records, the best source of historical production and marketing information is (or should be) the farm records maintained for the farm business. 
The records may be supplemented and complemented by off farm information, forecasts, and predictions. But there is no substitute for farm record data. Livestock production and cost information generated by farm records reflect the production capabilities of the specific assets controlled by the business. The business management capability is also reflected for both production and marketing aspects of the business. As such, this record information should provide insights into the actual production and price variability experienced by the farm business in the past [11].

Farm records are useful in a number of ways. They provide a good picture of the risk faced by the farmer in the past. The records also indicate how successful past risk management efforts were. Combining these historical results with the producer's risk preferences help to show what, if any, changes in risk management should be made in the future. Is the farm primarily bottom land prone to flooding? Are there hills on the farm which are susceptible to drought? Have these constraints contributed to as obstacles to transition from family farm to agribusiness? Would a change in cultural practices, or operation timing help to reduce farm risks and increase sustainability? Are animals sold in the farm, local markets or international markets? Which of the marketing method have been profitable for the family farm or agribusiness? The information provided by farm records should help answer some of these questions. If past production and marketing decisions have not provided desirable results, the records should show it. Record analysis also point out things that should be changed to provide better results that are more compatible with the manager's risk preferences. The kind of information not often available from family farms is that concerning technological, legal, institutional, and policy. Farm records would prove useful in providing information that can be used by farm operators or investors themselves and/or policy makers to make their investments profitable and sustainable.

\section{Literature review}

Livestock production entails rearing of farm animals e.g. cattle, sheep, poultry, goat, pig, rabbits, ducks) by an individual or group of people (Livestock farmers) for profit making. In the production process the animals are usually confined in a particular area (animal farm) and bred through the application of skilled and unskilled management techniques. It should be observed that different livestock species have different ways of managing them thus highlighting good stockman ship as a prerequisite of livestock production. Livestock production can be intensive or extensive [4]. The intensive production is characterized by smaller number of herd sizes (number of animal on the farm), sometimes characterized by limited use of high production technology. The extensive production system with a higher number of population uses advanced production methods. Livestock production is a function of associated cost of production and more importantly the management system in place [12].

Small scale farms are more viable than larger farms. They have advantages in labour management over large farms so that economies of scale do not apply beyond the family farm.
Small holdings may be disadvantageous when facing mounting demands from buyers, supermarkets and exporters for quality, consistency, timeliness, volume and certification of conditions of production. This could lead to the exclusion of small scale farmers from the market for higher value products [9]. In low income countries, traditional peasant agriculture tend to be characterized by low level utilization of certain resources, low levels of productivity, relatively high level of efficiency in combining resources and enterprise. The resources commonly not used are capital and technology and these are not accessible to farmers in low development. According to Zeller [13] small holder farmers can have the following characteristics.

The first characteristic of small scale agriculture is that there is a close relationship between decisions at the farm and at household operating the farm. The household and its members may not only manage the agricultural enterprise but engage as season or temporary wage workers. Other common sources of income are remittances and gifts and income from gathering fruits and vegetables. The importance of family and close relationship between production and consumption decisions occur between much of labour, management and capital come from the same household and its members. Furthermore a sizeable proportion of production is consumed on the same farm. The intermixing of production and consumption decisions along with low levels of income implies traditional farms households are not profit maximizers but pursue different objectives such as securing food and other basic needs, leisure time, generation of earning for purchase of market goods and services. Traditional farms consume most of their products at home. Also traditional farms are also influenced by market price relationships in their decision to allocate family resources. Most of the farm households in developing countries are also characterized by semi subsistence that is consuming part and selling part of their animals and crops [7].

Land and Labour use is another factor; Small scale farms in developing countries usually ranges from 1 to 3 hectares. Labour intensity per hectare tends to be high because of most of family labour with an average size of six is used for livestock and crop enterprise. Apart from water, land which is the main constraining factors in raising level of production, labour is often under-employed during certain periods of the year while capital assets that exist are fully exploited. Much sharing of work and income occurs in traditional farms which lead to little unemployment during slack times. The sharing means individuals implicit wage at times are determined by average rather than marginal productivity of labour. Family farms also may supplement their incomes by working off farm part time on larger farms or by engaging in share cropping contracts as tenants [13].

Productivity and Efficiency; Traditional farms are characterized by low use of purchased inputs rather than labour. Yields per hectare, production per person, and other measures of productivity tend to be low. Traditional farms tend to be poor but efficient. Efficiency measured by equating marginal returns to resources in alternative uses is high Zeller [13]. 
Livestock play a very important role in Cameroon agriculture, contributing about $9 \%$ of the total agricultural or about $2.1 \%$ of the Gross Domestic Product [14]. In 2007 the livestock population comprised about 9.790 million cattle, 6.872 million goats and 5.050 million sheep. These figures have since increased as per the statistics obtained in Table 1 [7]. Horses and asses are grazing species of relatively low economic importance. Accurate statistics on livestock production and marketing are not easy to obtain because of lack of an appropriate statistics collection system. Animal production has increased gradually between 2007 and 2016. This sub sector is a source of revenue to more than $30 \%$ of the rural population. Table 1 shows ruminant livestock production from 2007 to 2016 as collected and presented by the government statistics office in Yaoundé.

Cattle contribute about $54 \%$ of total meat consumption per (Capital) inhabitant in Cameroon, while the proportion for sheep and goat is $13 \%$, pig $15 \%$ and poultry $17 \%$. Cattle are found throughout Cameroon but the major production areas are in the North West and West region and from the Adamawa Region northward [7]. Herd size is very small in the sub-humid zone because of the high prevalence of trypanosomiasis. Beef production is almost entirely from extensive systems with low inputs. The traditional nomadic system has low productivity due to poor nutrition but has, over the years, met the major demand for beef in Cameroon. For hundreds of years local cattle have adapted to heat, harsh local conditions and management, and developed some resistance to the various environmental stresses [7].

Table 1: Ruminant livestock population.

\begin{tabular}{|c|c|c|c|c|c|}
\hline \multirow{2}{*}{ Years } & \multicolumn{5}{|c|}{ Livestock (000) } \\
\cline { 2 - 6 } & Cattle & Goats & Sheep & Asses & Horse \\
\hline 2016 & 15644 & 12672 & 10850 & 236 & 48 \\
\hline 2015 & 14404 & 12222 & 10100 & 137 & 48 \\
\hline 2014 & 14144 & 11850 & 9850 & 137 & 37.0 \\
\hline 2013 & 13500 & 10872 & 9850 & 122 & 37.0 \\
\hline 2012 & 11315 & 8600 & 8155 & 122 & 34 \\
\hline 2011 & 11090 & 8600 & 8050 & 122 & 34 \\
\hline 2010 & 11090 & 8087 & 7500 & 118 & 34 \\
\hline 2009 & 10890 & 7800 & 6456 & 92 & 32.5 \\
\hline 2008 & 9877 & 7402 & 5250 & 92 & 29.5 \\
\hline 2007 & 9790 & 6872 & 5050 & 88 & 29 \\
\hline
\end{tabular}

Source: Government of Cameroon, 2017 [6].

\section{Methodology}

\section{Presentation of study area}

The North West is one of the regions in Cameroon; it is composed of seven divisions: Boyo, Bui, Menchum, Mezam, Momo, Ngo-Ketunjia and Donga-Mantung Division. Bamenda which is the Capital City of the region is found in Mezam Division. This study covers Bamenda town and its peripheries that is Urban and Periurban respectively. The study area thus covers two Divisions (Mezam and Momo division). Bamenda is located between latitude $5.55^{\circ}$ North and $10.09^{\circ}$ East. As at 2010, the projected total population of the North West region was 2.090.300 million inhabitants with Mezam alone having 802.100 inhabitants. Mezam division is divided into five subdivisions namely: Bafut, Bali, Bamenda, Santa and Tubah. It has a surface area of $2870 \mathrm{~km}^{2}$ and a population density of 279 people per square kilometer. Bamenda is seen as the highest trading center in the region since almost all the main commercial activities are located there. This area was considered ideal for this study due to its high potential production and marketing of livestock. The population growth in Bamenda is fast increasing because of rural exodus. The high search of job opportunities and growth of economic activities has caused the demand for livestock products and food stuffs to increase. There is therefore the need to increase farm productivity to meet the growing population all over the North West Region and Bamenda in particular [7] Figure 1.

\section{Research design, study population and sampling pro- cedure}

The study used a cross sectional survey in which data was collected from several points. These points composed of livestock-keeping households in Bamenda and its surrounding areas. Amongst others, the baseline survey covered aspects on household demographics, production practices, identification of constraints to production and possible solutions, and management practices (feeding, watering, breeding and health provision).

The target population of the study was livestock farmers. Using the google earth map, twenty urban and twenty periurban points were randomly selected based on settlement, followed by a random selection of at most four livestock farmers per point to participate in the study. Points were being located by the use of Google Maps on Smart Phones. The procedure consists of entering coordinates of a point at a time in Google Maps and it immediately shows the direction of the point. Random sampling procedure was used to reduce biasness due large number of livestock farmers available at some points in study area.

\section{Data source, collection and analyzing technique}

The following tools were used for data collection: questionnaires, pencils, eraser, sharpener, exercise book (40 Leaves), a four wheel drive car, rain boots, disinfectant, Smart phone, Global Positioning System, and gifts for the farmers (3 Savons per farmer)

The primary data from the sampled livestock farmers were collected through formal survey by using a structured questionnaire. The questionnaire was pre-tested before the main survey to check the relevance of questions and to determine whether it was comprehensive enough to collect the required information. The information focus on livestock ownership, priority species kept, purpose for keeping livestock, feeding management, animal health and main problems of livestock keeping. Secondary data were collected from the Divisional 


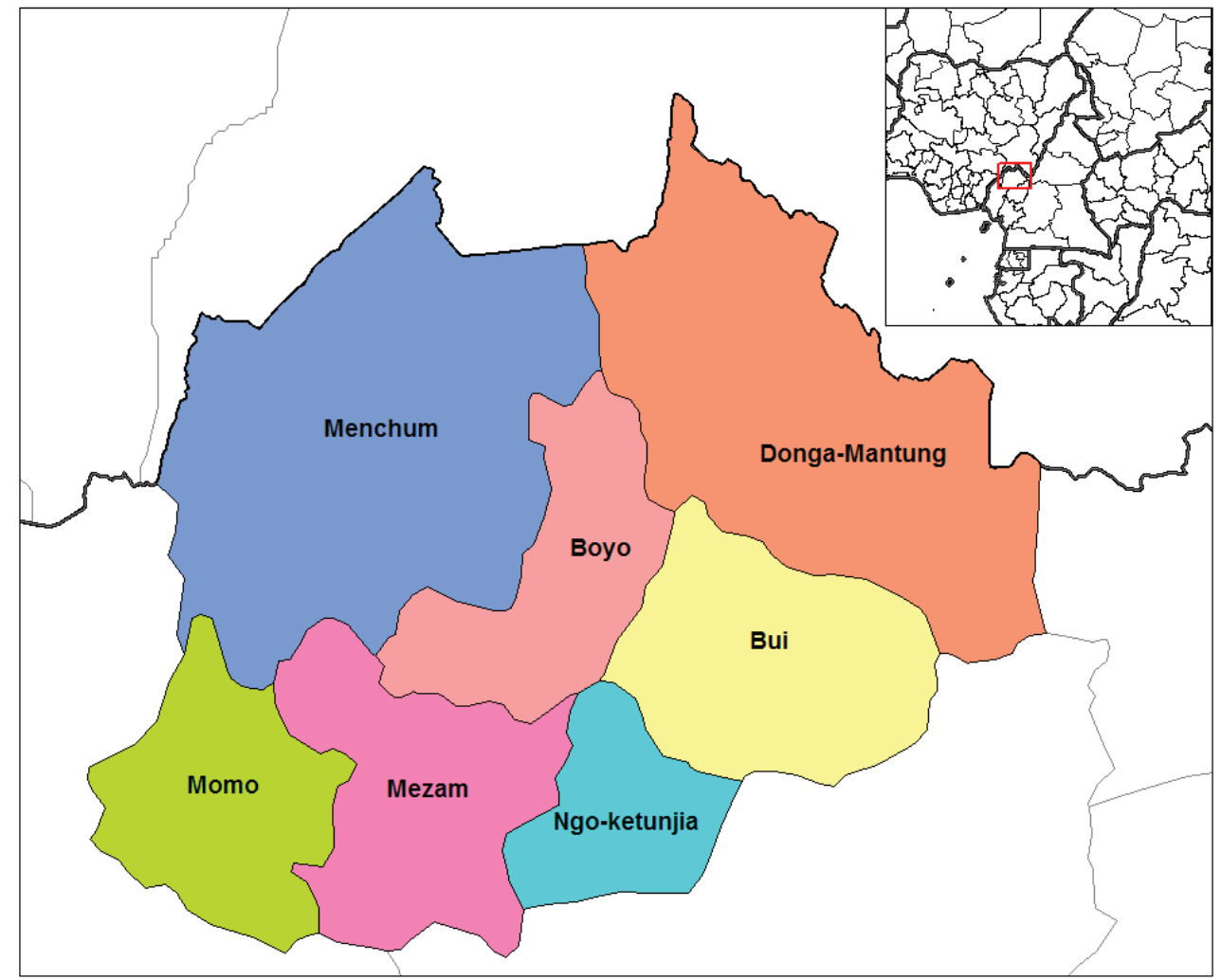

Figure 1: Map of the North West Region of Cameroon showing the Divisions.

Source: Created by Rarelibra 19:55, 1 September 2006.

Delegation for Livestock, Fisheries and Animal Industries and internet. A total of 160 respondents were obtained and interviewed for this study. Although sample size was limited to 160 it was sufficient enough to allow for statistical analysis. Usually the sample size depends on the size of the population to be sampled although general rule were hard to make without knowledge of specific population The data obtained was summarized, coded, and analyzed by using Statistical Package for Social Sciences computer program version 20. Descriptive statistics was generated to represent respondents' opinions on various aspects of livestock production and these include frequencies, means, standard deviations, tables, pie chart, bar chart, cumulative frequencies and percentages.

\section{Results and Discussions}

\section{Social economic characteristics of livestock farmers}

These characteristics present socio economic aspects of respondents. Social economic characteristics have effects on the farmers' production decisions and resource allocation. They determine human potential to produce and capacity to change production practices and technology in this everchanging social and economic environment [8]. Survey results in Figure 2 indicated that $13.8 \%$ of household heads members were aged between $20-35$ years while $29.4 \%$ were 36 -50 years old, $34.4 \%$ were $51-65$ years and $22.5 \%$ were above 65 years old. The age of household head ranged from 23 years to a maximum of 90 years with the mean age of 53.6313 years old. These findings imply that majority of breeders fall between the age group of 51-65 years who are not energetic enough, as such capable to undertake livestock production activities. The age group of the livestock farmers influences livestock production very much. The activities associated with livestock production are less energy demanding but requires much experience as compared to other activities like cultivating crops. This explain why majority of breeders fall between the ages 51-65 years. Balgah [14] urges that in total the accumulation of wealthy is highly dependent on age of an individual, whereby an indirect relationship is experienced. The interviewed livestock farmers in the study areas fall in economically non-productive class, which are dependents.

Furthermore, Figure 2 show that $89.4 \%$ of farmers were married and male headed, $10 \%$ singled and $0.6 \%$ was married. Married respondents are expected to have children who determine the size of household family members anticipated to provide supplementary household labour for Irish potato production. However, when the household has more children than adults it means that the household has too many dependents and hence low economically productive class. Balgah [14] reported that education is a factor of growth and productivity. The findings indicated that $63.8 \%$ of interviewed farmers had primary education, $11.3 \%$ had secondary education, $8.8 \%$ attended high school, $13.1 \%$ degree holders and $3.1 \%$ attended no formal education. These findings showed a typical characteristic of literacy common for family farm operators in 


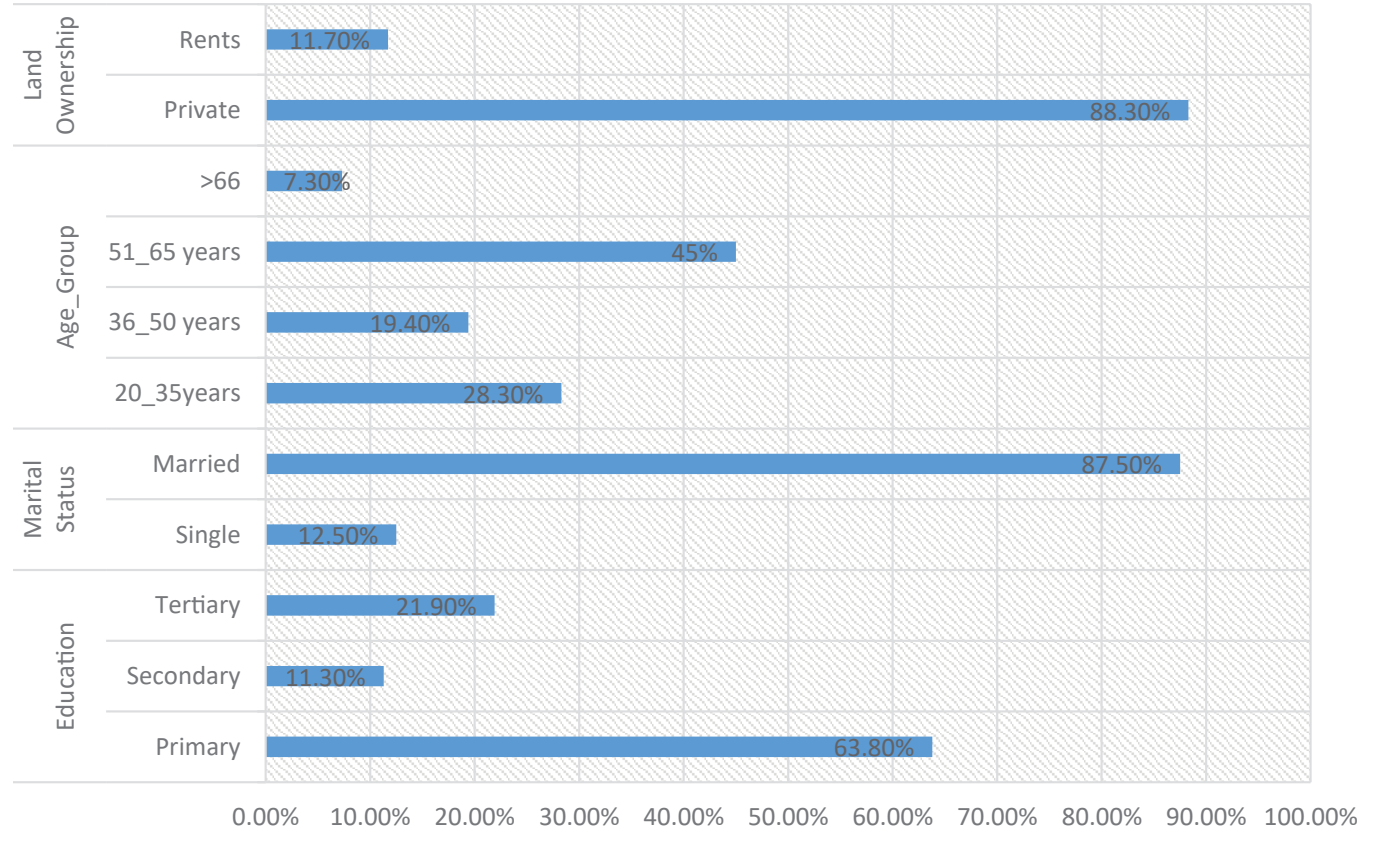

Figure 2: Social economic characteristics of livestock farmers. Source: Author.

the study area. The implication of this is that, the majority of household heads in the study area have basic education enough for them to seek or receive better livestock production and management technologies available from different sources such as Research Stations, extension agent, publications and mass media.

Land is a major resource in agricultural production, but keeping of animals does not require much land as compared to the cultivation of crops. Findings indicate that sizes of livestock family farms owned by respondents are small and owned by the individuals. Figure 2 shows that $88.125 \%$ of farm land is private (owned by the household) and $11.875 \%$ is rented.

\section{Animal species and purpose of keeping on the farm}

Livestock species in the study area vary from cow, goats, sheep, pig, indigenous fowls, commercial birds, ducks and rabbits. Different households have different reasons for keeping different species on farm such as; sale of live animal, sale of meat, sale of milk, collection of manure, consumption of meat, prestige and culture/religion etc. Findings in this work shows that $78.75 \%$ of respondents rear pigs, $76.875 \%$ own table birds, $26.25 \%$ own goats, $5.625 \%$ own sheep, $3.125 \%$ own cow, $3.125 \%$ own rabbits and $2.5 \%$ respondents own ducks (Table 2). The highest specie of animal raised by households in the study area are pigs (126 respondents own pigs on their farms out of 160 respondents) and table birds were the second most numerous species kept in the study area. They can also be a source of income as they are easy to sell when need arises compared to larger species like cattle. According to Muchadeyi [15-17], they are a form of quick off-takes thus they play a major role in the livelihoods of farmers Table 2.
Table 2: Animal Species and Uses.

\begin{tabular}{|c|c|c|c|c|}
\hline Specie & $\begin{array}{c}\text { Total } \\
\text { Observation }\end{array}$ & $\begin{array}{c}\text { Absolute } \\
\text { frequency }\end{array}$ & $\begin{array}{c}\text { Relative } \\
\text { frequency }\end{array}$ & Percentage \\
\hline Cow & 160 & 5 & 0.03125 & 3.125 \\
\hline Goat & 160 & 42 & 0.2625 & 26.25 \\
\hline Sheep & 160 & 9 & 0.05625 & 5.625 \\
\hline Pig & 160 & 126 & 0.7875 & 78.75 \\
\hline $\begin{array}{c}\text { Table birds (indigenous fowls } \\
\text { and commercial birds) }\end{array}$ & 160 & 123 & 0.76875 & 76.875 \\
\hline Duck & 160 & 4 & 0.025 & 2.5 \\
\hline Rabbit & 160 & 3 & 0.03125 & 3.125 \\
\hline Purpose for keeping animals & & \\
\hline Sale of live animal & 160 & 151 & 0.94374 & 94.375 \\
\hline Sale of meat & 160 & 21 & 0.13125 & 13.125 \\
\hline Local Consumption of meat & 160 & 126 & 0.7875 & 78.75 \\
\hline Collection of manure & 160 & 138 & 0.8625 & 86.25 \\
\hline Prestige & 160 & 1 & 0.00625 & 0.625 \\
\hline Culture & 160 & 4 & 0.025 & 2.5 \\
\hline
\end{tabular}

Source: Author.

The purpose for keeping different livestock species was ranked as show on table..below. Sale of life animals was ranked first $(94.375 \%)$, collection of manure second $(86.25 \%)$, local consumption third (78.75\%) and others; $13.125 \%$ sale of meat, $2.5 \%$ as culture and $0.625 \%$ for prestige. Out of the 151 respondents who keep animals to sell alive, 61 of them keep pigs and 59 of them own poultry. The ranking was done based on three most important reasons; Rank 1: most important, Rank 2: very important, Rank 3: important. All the above findings permitted us to answer our second research question Table 3. 


\section{Management strategies on family farms for sustainabi- lity and food insecurity}

Family members who take part in the management of the farm play a great role in the sustainability of family farms. Table 4 shows that $68.1 \%$ of family farms are managed by household heads, $29.9 \%$ by spouses, $4.4 \%$ by sons/daughters and $0.6 \%$ by others. Table 4 shows that $43.8 \%$ of households own two species of animals on farm, $36.3 \%$ own one specie on farm, $17.5 \%$ own three species, $1.9 \%$ own four species and $0.5 \%$ own five and above. A result of $63.7 \%$ respondents who own at least two species on farm is a guarantee for the existence of the farm in case of a disease outbreak in any of the specie. Figure 2 shows that only $8.75 \%$ of livestock farmers keep records compared to $91.25 \%$ keep records. This is a big risk because past activities which were not successful have the possibility of repeating themselves Table 4 .

Other management practices for sustainability on family farms include: household members who belong to Common Initiative Groups, years of experience of farm manager, constant monitoring of farm, own males on farm for breeding to reduce production cost and avoid diseases.

Table 3: Reasons for owning different species on farm.

\begin{tabular}{|c|c|c|c|c|c|c|c|c|c|c|}
\hline \multirow{2}{*}{ Purpose } & C & G & S & P & Po & \multicolumn{2}{c|}{ Others } & \multirow{2}{*}{ Frequency } & RANK \\
\hline Sale of live animals & 3 & 20 & 4 & 61 & 59 & 2 & 2 & 151 & $\mathrm{R}_{1}$ \\
\hline Manure & 2 & 18 & 4 & 56 & 54 & 2 & 2 & 138 & $\mathrm{R}_{2}$ \\
\hline Consumption of meat & 2 & 17 & 4 & 50 & 49 & 2 & 2 & 126 & $\mathrm{R}_{3}$ \\
\hline $\begin{array}{c}\text { Sale of meat } \\
\text { Culture/Religion }\end{array}$ & 0 & 3 & 1 & 9 & 8 & 0 & 0 & 21 & $\mathrm{R}_{4}$ \\
\hline Prestige & 0 & 0 & 0 & 2 & 2 & 0 & 0 & 4 & $\mathrm{R}_{5}$ \\
\hline Consumption of milk & 0 & 0 & 0 & 1 & 0 & 0 & 0 & 1 & $\mathrm{R}_{6}$ \\
\hline Sale of milk & 0 & 0 & 0 & 0 & 0 & 0 & 0 & 0 & - \\
\hline Draught power & 0 & 0 & 0 & 0 & 0 & 0 & 0 & 0 & - \\
\hline Sale of other animal products & 0 & 0 & 0 & 0 & 0 & 0 & 0 & 0 & - \\
\hline Other (specify) & 0 & 0 & 0 & 0 & 0 & 0 & 0 & 0 & - \\
\hline
\end{tabular}

Source: Author, NB: C: Cow; G: Goat; S: Sheep; P: Pig and Po: Poultry

Table 4: Management Strategies on Family Farms for Sustainability and Food Insecurity.

\begin{tabular}{|l|l|l|l|}
\hline Manager & Frequency & Valid Percent & Cumulative \%
\end{tabular}

Participation of household members on farm

\begin{tabular}{c|c|c|c|}
\hline Household & 109 & 68.1 & 68.1 \\
\hline Wife & 43 & 26.9 & 95.0 \\
\hline Son/Daughter & 7 & 4.4 & 99.4 \\
\hline Other & 1 & 0.6 & 100.0 \\
\hline
\end{tabular}

Animal species owned per household (Diversification)

\begin{tabular}{|c|c|c|c|}
\hline Own one specie on farm & 58 & 36.3 & 36.3 \\
\hline Own two species on farm & 70 & 43.8 & 80.0 \\
\hline Own three species on farm & 28 & 17.5 & 97.5 \\
\hline Own four species on farm & 3 & 1.9 & 99.4 \\
\hline Own 5 species and above & 1 & 0.5 & 100.0 \\
\hline Farmer keep record & Farm Record & & \\
\hline Farmer does not keep record & 14 & 8.75 & 8.75 \\
\hline
\end{tabular}

Source: Author.

\section{Conclusion}

A large agenda of work still remains concerning the robust prediction of animal growth, body composition, feed requirements, and the outputs of waste products from the animal and production costs. Such work could go a long way to help improve the efficiency of livestock production and meeting the expectations of consumers and the demands of regulatory authorities. The findings from this study suggested the existence of various opportunities, however, there exist for improving livestock production in communal areas and some of the possible technologies are not new to farmers. The increasing demand for livestock products continues to be a key opportunity for poverty reduction and economic growth, although the evidence of the last 10 years suggests that only a few countries have taken advantage of this opportunity effectively. Majority of livestock farmers did not keep any form of record from their farm activities. For sustainable development in Cameroon, quality feed at lesser cost, new breeds of animals and access to credit be made available to farmers.

Based on our analysis, we recommend that: information on innovations in livestock production should be made available to farmers to improve their production. Financial assistance should be given to the farmers to acquire farms inputs like feed, drugs, wheelbarrow, modern feeding and drinking trough and other materials for farming activities. Livestock farmers equally need to be encouraged by providing necessary assistance such as adequate training, appropriate technologies for production and good marketing system for their production. Farmers should cultivate crops for their animals and compose their own feed for it will be less expensive.

\section{References}

1. Folefack JA, Tsafack PP, Kamjou F (2018) Logit Model of Analyzing the Factors Affecting the Adoption of Goat Raising Activity by Farmers in the Non-pastoral Centre Region of Cameroon. Tropicultura 36: 54-62. Link: https://bit.ly/34cwoHD

2. Sasson A (2012) Food security for Africa: an urgent global challenge, Agriculture \& Food Security Review 1: 1-16. Link: https://bit.ly/2Wc47fT

3. Lipton M (2006) Can small farmers survive, prosper, or be the key channe to cut mass poverty? The Electronic Journal of Agricultural and Development Economics 3: 58-85. Link: https://bit.ly/3mfTEuG

4. Muluh GN, Kimengsi JN Azibo NK (2019) Challenges and Prospects of Sustaining Donor-Funded Projects in Rural Cameroon. Sustainability 11: 6990. Link: https://bit.ly/3niPJhl

5. Minepat (2010) Ministry of the Economy, Planning and Regional Development (MINEPAT). Growth and Employment Strategy Paper Yaoundé, Cameroon. Link: https://bit.ly/3oPUKyN

6. Perera O, Jayasuriya N (2008) The dairy Industry in Sri Lanka: Current status and future directions for a greater role in national development Journal of the National Science Foundation of Sri Lanka 36: 115-126. Link: https://bit.ly/37dpKmu

7. Government of Cameroon (2017) Livestock Statistics from Ministry of Agriculture and Rural Development, 2017 Report of Department of Statistics, Working Tool 34-74.

Citation: Tambi MD, Anyah FJ (2020) Transitional Opportunities of the Family Farms to Agribusiness in Livestock Production in Cameroon. J Agric Sc Food Technol 6(2): 229-236. Ol: https://dx.doi.org/10.17352/2455-815X.000079 
8. Masikati P (2010) Improving the water productivity of integrated croplivestock systems in the semi-arid tropics of Zimbabwe: an ex-ante analysis using simulation modelling. Link: https://bit.ly/34bemWi

9. Kassam AH (2009) Rethinking agriculture. Agriculture for Development 1 (Spring), 29-32. Rothes, UK: Tropical Agriculture Association Jonathan 2013.

10. King DA, Peckham C, Waage JK, Brownlie J, Woolhouse MJ (2006) Infectious diseases: preparing for the future. Science 313: 1392-1393. Link: https://bit.ly/3ngM2t5

11. Ellis $F$ (2012) Small farms, Livestock diversification and rural-urban transitions: strategic issues in Sub Saharan Africa. Overseas Development Group (ODG). University of East Anglia Norwich NR47TJ, UK

12. Waiswa C, Olaho-Mukani W (2003) Domestic animals as reservoirs for sleeping sickness in three endemic foci in South-Eastern Uganda. Ann Trop Med Parasitol 97. Link: https://bit.ly/3808Sij
13. Zeller M, Sharma M (2000) Rural finance and poverty alleviation. Food Policy Report. International Food Policy Research Institute (IFPRI): Washington, DC.

14. Balgah RA (2018) The Programme for the Improvement of Agro-Pastoral Family Farms and Poverty Reduction in Mezam Division, Cameroon. Univ Buea J Appl Soc Sci 2: 1-24.

15. Muchadeyi FC (2007) Assessment of genetic diversity of Zimbabwe village chicken ecotypes. Cuvillier, Goettingen 137. Link: https://bit.ly/3qSU1ib

16. Djamen $P$, Lossouarn J, Havard M (2006) Transformation of livestock farming in Cameroon: Changes in breeding practices and evolution of farmer profiles. Wageningen Academic Publishers 285. Link: https://bit.ly/3gK2Vtx

17. Dijkman J (2009) Innovation capacity and the elusive livestock revolution. Link News Bulletin. Link: https://bit.ly/3gJsefq
Discover a bigger Impact and Visibility of your article publication with Peertechz Publications

\section{Highlights}

* Signatory publisher of ORCID

* Signatory Publisher of DORA (San Francisco Declaration on Research Assessment)

* Articles archived in worlds' renowned service providers such as Portico, CNKI, AGRIS, TDNet, Base (Bielefeld University Library), CrossRef, Scilit, J-Gate etc.

* Journals indexed in ICMJE, SHERPA/ROMEO, Google Scholar etc.

* OAI-PMH (Open Archives Initiative Protocol for Metadata Harvesting)

* Dedicated Editorial Board for every journal

* Accurate and rapid peer-review process

* Increased citations of published articles through promotions

* Reduced timeline for article publication

Submit your articles and experience a new surge in publication services

(https://www.peertechz.com/submission).

Peertechz journals wishes everlasting success in your every endeavours.

Copyright: @ 2020 Tambi MD, et al. This is an open-access article distributed under the terms of the Creative Commons Attribution License, which permits unrestricted use, distribution, and reproduction in any medium, provided the original author and source are credited. 